\title{
THE IMPROVEMENT OF CHEMISTRY AND PHYSICS INSTRUCTION IN AMERICAN HIGH SCHOOLS.
}

By Earl R. GLenN,

The Lincoln School of Teachers College, Columbia University. I

In discussing the improvements that are possible in chemistry and physics instruction, it is well to keep in mind the fact that the higher institutions still exercise a large measure of control over the course taken by a high school student.

According to a government bulletin ${ }^{2}$ the distribution of prescribed units for entrance to state colleges and universities in 1915 was as follows:

(a) Thirty-six states require three years or more of English

(b) Thirty-seven states require two years or more of mathematies

(c) Thirty states require two years or more of foreign language

(d) Two states require as much as two years of seience and none require more

(e) Nineteen states require one year of science. In more than onehalf of the states a student may enter the state colleges or universities with no previous seience training.

So long as these requirements exist to the disadvantage of science instruction, a large percentage of the high school population will never be enrolled in science classes, no matter how interesting or valuable the science courses may be.

\section{II}

As chemistry and physics teachers, we should adopt such a science sequence as that suggested by the N. E. A. Commission on the Reorganization of Secondary Education. ${ }^{3}$ Until the science teachers do agree upon some science sequence it will not be possible to compete with English, foreign language, and mathematics, or to obtain information about the learning processes or the "grade-placement" of the extensive and complicated subject matter of science.

\section{III}

At the present time, the teaching of chemistry and physics has reached such a state of development that we may well discard some of the methods of teaching used in higher institututions that have been found through extensive trial by competent observers not to function in high school instruction. To this end the high school science lecture room should be omitted from the designs of all new high school buildings and there should be substituted for it a unit science laboratory which is designed 
for class demonstration or individual laboratory work, all of which in a single room is under the control of the class teacher. Such designs will be found in the Central Technical School, Toronto, Canada, The Lincoln School of Teachers' College, New York, and Girard College, Philadelphia.

\section{IV}

As teachers we are too uncritical of the subject matter that we use for instruction. From time to time both laboratory manuals and textbooks need to be evaluated in an objective way: The content of such influential examinations as those given by the College Entrance Examination Board should also be examined critically. This has recently been done for chemistry ${ }^{4}$ with the following conclusions:

Distribution of the Subuect Matter of Chemistry QuesTIONS, 1911-1920.

\begin{tabular}{|c|c|c|c|}
\hline \multirow[b]{2}{*}{ Topic } & \multicolumn{3}{|c|}{ Per cent of Frequency } \\
\hline & Old Plann & $\begin{array}{c}\text { Compre- } \\
\text { hensive }\end{array}$ & All \\
\hline $\begin{array}{l}\text { Common non-metallic elements } \\
\text { Common metallic elements } \\
\text { Common acids } \\
\text { Salts, oxides and hydroxides } \\
\text { Gases (not elements) } \\
\text { Organic substances } \\
\text { Identification (laboratory) } \\
\text { Quantitative experiments } \\
\text { Equations } \\
\text { Reversible reactions } \\
\text { Laws and Theories } \\
\text { Electrolytic Dissociation Theory } \\
\text { Chemical arithmetic: } \\
\text { Percentage composition } \\
\text { Weights of substances concerned } \\
\text { Volumes of gas from a reaction } \\
\text { Energy changes } \\
\text { Oxidation and reduction } \\
\text { Solutions } \\
\text { Others }\end{array}$ & $\begin{array}{r}8.0 \\
4.2 \\
7.8 \\
17.9 \\
7.5 \\
2.5 \\
11.6 \\
0.55 \\
12.4 \\
1.0 \\
6.3 \\
3.1 \\
1.5 \\
1.7 \\
3.0 \\
0.55 \\
1.7 \\
1.5 \\
7.2\end{array}$ & $\begin{array}{r}9.0 \\
2.6 \\
10.2 \\
7.6 \\
6.1 \\
2.6 \\
7.6 \\
0.6 \\
17.8 \\
2.2 \\
5.2 \\
5.2 \\
2.3 \\
1.7 \\
3.2 \\
0.9 \\
1.5 \\
2.9 \\
10.8\end{array}$ & $\begin{array}{r}8.4 \\
3.6 \\
8.7 \\
13.8 \\
6.9 \\
2.5 \\
10.0 \\
0.6 \\
14.5 \\
1.4 \\
5.9 \\
3.9\end{array}$ \\
\hline Total & 100.0 & 100.0 & 100.0 \\
\hline
\end{tabular}

We have made a similar study for physics and while the complete summary is not yet published, the following facts appear to be significant for "the old plan" questions:

a. Questions and parts of questions for ten years distributed by definitions of terms, laws, physical phenomena to be explained, problems, and experiments.

b. The equations for Ohm's law appear with a frequency of 19 times that of the equation for relative humidity.

$\dot{c}$. Problems involving the gas laws appear seven times as often as those involving the variation of light intensity with distance.

"Geiry, Henry L., "College Entrance Examination Board Questions in Chemistry;" Schoor Scimen and Mathenatics, 20 (1920), 845-50. 
d. Twenty different formulas were asked for only once in a period of ten years.

\begin{tabular}{l|c|c|c|c|c|c}
\hline Division & Mechanies & Heat & Electricity & Sound & Light & Total \\
\hline $\begin{array}{l}\text { Physical } \\
\text { terms }\end{array}$ & 19 & 9 & 0 & 5 & 3 & 36 \\
\hline $\begin{array}{l}\text { Physical } \\
\text { phenomena }\end{array}$ & 11 & 5 & 16 & 11 & 35 & 78 \\
\hline $\begin{array}{l}\text { Laws and } \\
\text { facts }\end{array}$ & 35 & 5 & 5 & 14 & 7 & 66 \\
\hline \begin{tabular}{l} 
Problems \\
\hline Experiments
\end{tabular} & 43 & 19 & 32 & 8 & 25 & 127 \\
\hline \multicolumn{1}{|c|}{ Total } & 7 & 3 & 2 & 4 & 1 & 17 \\
\hline
\end{tabular}

V

Since our school promotions depend upon tests of one sort or another it is time that we, as teachers of exact science, should make our examinations less burdensome to teacher and pupil and somewhat more exact.

This is important for three reasons:

a. Teachers marks are unreliable.

b. The marks given by teachers show a striking variability.

c. Teachers are inconsistent in the distribution of class marks.

The investigations which support these statements are summarized by H. O. Rugg in the Elementary School Journal ${ }^{5}$ for May, 1918. Any who wish to examine the evidence in detail should read this valuable article. In all probability these three fundamental criticisms of our marking system apply to a considerable extent to teachers of chemistry and physics. Some new tests are now being devised for these subjects and any who are interested should communicate with the author. The methods used in devising and scoring tests are discussed in the references on educational measurements which are listed below.

\section{VI}

Some Books on Educational Tests.

1. Burgess, May Ayres, "The Measurement of Silent Reading," 1921, Russell Sage Founda-

2. Caldwell, Otis W., "Science in the Gary Schools," 1919, General Education Board, New York.

3. Monroe, Walter S. "Measuring the Results of Teaching," 1918, Houghton.

4. Rugg, Harold O." "Statistical Methods Applied to Education," 1917, Houghton.

5. Terman, I. M." "The Intelligence of School Children." 1919, Houghton.

6. Wilson, G. M. and Hoke, K. J., "How to Measure," 1920, Macmillan.

7. Yockum, C. S. and Yerkes, R. M., "Army Mental Tests," 1020, Holt.

'Rugg, H. O., "Teachers' Marks and the Reconstruction of the Marking System," Elementary School fournal, 18 (1918), 701-19. 